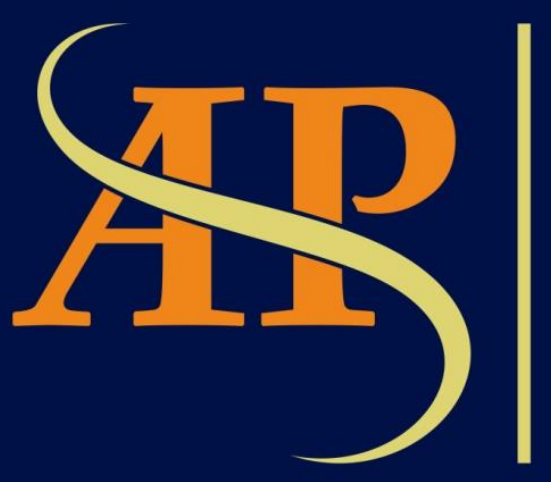

JURNAL

ASIA

PACIFIC

STUDIES

Journal of International Relations Study Program Faculty of Social and Political Sciences

Universitas Kristen Indonesia

Volume 3 | Number 2 | July - December 2019 


\title{
PERSAINGAN PENGARUHDI PASIFIK SELATAN: PENGALIHAN DUKUNGAN DIPLOMATIK KEPULAUAN SOLOMON DARI TAIWAN KE TIONGKOK
}

\author{
Adinda Normala Putri \\ Program Studi Ilmu Hubungan Internasional, Fakultas Ilmu Sosial dan Politik, Universitas Indonesia, Jl. Prof. \\ Dr. Selo Soemardjan, Depok, Jawa Barat 16424 Indonesia \\ adindanormala@gmail.com
}

\begin{abstract}
The Solomon Islands shifted their diplomatic support from Taiwan to China in September 2019 after 36 years of diplomatic relations, which was followed by Kiribati, leaving Taiwan with only four South Pacific countries that still formally recognize it. Chin a and Taiwan have long been the main actors in the competition for influence in the South Pacific, which is mainly due to the capacity of the Pacific islands to provide diplomatic recognition, where the pressure exerted by China on Taiwan has intensified since the election of Taiwan President Tsai Ingwen in 2016. This journal discusses the motives of the Solomon Islands to turn to China, using the bandwagoning theory by Randall L. Schweller with the argument that the Solomon Islands bandwagons the wave of the future, a decision taken because the ally is considered to represent the future. The method used in this journal is a qualitative method that aims to describe and analyze a phenomenon systematically, which will explain the motive behind the Solomon Islands decision to shift its diplomatic support supported by theory and secondary data. This journal will first elaborate on China and Taiwan's rivalry in the South Pacific and continue with the Solomon Islands' motives to shift their diplomatic support from China to Taiwan.
\end{abstract}

Keywords: Solomon Islands, China, Taiwan, bandwagoning

\begin{abstract}
Abstrak
Kepulauan Solomon mengalihkan dukungan diplomatiknya dari Taiwan ke Tiongkok pada September 2019 setelah 36 tahun memiliki hubungan diplomatik, yang diikuti oleh Kiribati, meninggalkan Taiwan dengan sisa empat negara Pasifik Selatan yang masih mengakuinya secara internasional. Tiongkok dan Taiwan telah lama menjadi aktor utama dalam persaingan pengaruh di Pasifik Selatan, yang disebabkan terutama oleh kapasitas Kepulauan Pasifik untuk memberikan pengakuan diplomatik, di mana tekanan yang diberikan oleh Tiongkok terhadap Taiwan semakin intensif sejak terpilihnya Presiden Taiwan Tsai Ing-wen pada tahun 2016. Jurnal ini membahas tentang motif Kepulauan Solomon berpindah haluan ke Tiongkok, dengan menggunakan teori bandwagoning yang dicetuskan oleh Randall L. Schweller dengan argumen bahwa Kepulauan Solomon melakukan bandwagoning wave of the future, yang dilakukan karena pihak sekutu dianggap merepresentasikan masa depan. Metode yang digunakan dalam jurnal ini adalah metode kualitatif yang bertujuan menggambarkan dan menganalisa suatu fenomena secara sistematis. Metode ini akan menjelaskan motif di balik keputusan Kepulauan Solomon mengalihkan dukungan diplomatiknya didukung dengan teori dan data sekunder. Adapun dalam pembabakan jurnal ini, akan dijabarkan rivalitas Tiongkok dan Taiwan di Pasifik Selatan dan dilanjutkan dengan motif di balik keputusan Kepulauan Solomon mengalihkan dukungan diplomatiknya dari Tiongkok ke Taiwan.
\end{abstract}

Kata kunci: Kepulauan Solomon, Tiongkok, Taiwan, bandwagoning 


\section{Pendahuluan}

\subsection{Latar Belakang}

Pada September 2019, Kepulauan Solomon mengalihkan pengakuan diplomatiknya dari Taiwan ke Tiongkok. Ini merupakan pukulan telak bagi Taiwan karena Kepulauan Solomon adalah negara terbesar di antara enam negara Kepulauan Pasifik yang memiliki hubungan resmi dengan Taiwan sebelum beralih. Saat ini, negara di Pasifik Selatan yang memiliki hubungan diplomatik dengan Taiwan berkurang menjadi empat karena Kiribati ikut memutus hubungan dengan Taiwan setelah Kepulauan Solomon (Zhang 2019). Kepulauan Solomon telah menjadi sekutu diplomatik Taiwan sejak Maret 1983, dan membuka kedutaan besar di Taiwan pada Mei 2005. Taiwan telah memberikan bantuan besar bagi sektor-sektor seperti pertanian, pendidikan, dan kesehatan di Kepulauan Solomon. Salah satu contoh adalah dukungan ekonomi Taiwan untuk Rural Constituency Development Fund atau Dana Pembangunan Pedesaan, yang dilaporkan bahwa pada 2017 Taiwan menyalurkan \$29,3 juta untuk dana program tersebut. Sebagai imbalannya, Kepulauan Solomon telah menyuarakan dukungan untuk partisipasi Taiwan dalam badan-badan PBB (Yin 2018).

Pernyataan resmi dari para pemimpin Kepulauan Solomon dalam beberapa tahun terakhir telah mengindikasikan bahwa dukungan Kepulauan Solomon terhadap Taiwan dapat berubah. Pada Mei 2013, perdana menteri saat itu Gordon Lilo menekankan bahwa kebangkitan Tiongkok tidak dapat diabaikan tetapi harus diperhitungkan dalam perdagangan dan hubungan luar negeri Kepulauan Solomon. Pada Desember 2014, penggantinya Manasseh Sogavare mengisyaratkan kemungkinan peralihan ke Tiongkok. Pada saat itu, sudah terjadi diskusi di media sosial di Kepulauan Solomon, terutama oleh generasi muda, tentang pertanyaan apakah Kepulauan Solomon akan beralih ke Tiongkok karena meningkatnya ikatan ekonomi dengan Tiongkok. Peran yang dimainkan oleh perdagangan dalam membentuk pandangan ini hanyalah salah satu faktor yang mendorong perkembangan baru ini. Ada beberapa dukungan yang mengakar kuat untuk beralih ke Tiongkok oleh mantan politisi Kepulauan Solomon, di mana mereka telah mengunjungi Tiongkok dan memiliki hubungan dekat dengan bisnis Tiongkok di Kepulauan Solomon yang masih memiliki hubungan kuat dengan bisnis dan keluarga di Tiongkok (Zhang 2019).

Sejak akhir Perang Dunia II, struktur kekuasaan di Asia-Pasifik didominasi oleh Amerika Serikat. Keseimbangan kekuatan di wilayah tersebut telah dibentuk oleh peran penting yang dimainkan oleh tatanan Amerika Serikat berdasarkan tujuan kebijakan keamanan dan kemakmuran di mana Amerika Serikat mempertahankan hegemoni dengan membangun jaringan keamanan. Namun, seiring dengan pergantian abad kedua puluh satu, terdapat perubahan pusat gravitasi keseimbangan kekuatan global yang bergeser dari Eropa ke Asia Pasifik, terutama disebabkan oleh kebangkitan Tiongkok. Dengan perubahan sistemik yang signifikan dalam tatanan internasional ini, pengaruh lama Amerika di Asia Pasifik dihadapkan dengan tantangan yang berat. Tiongkok menggantikan Jepang menjadi ekonomi terbesar kedua di dunia dan segera mengikutinya dengan menjadi negara dengan anggaran militer terbesar kedua (Jash 2017). Kekuatan Tiongkok yang terus berkembang, terlihat dengan pembentukan lembaga keuangan multilateral Asian Infrastructure Development Bank (AIIB) dan proyek jalur transportasi dan perdagangan Belt Road Initiative (BRI) yang menantang supremasi lama Amerika Serikat, telah menghasilkan keseimbangan kekuatan baru. Terlepas dari perkembangan ekonomi yang melesat, ketegasan militer Tiongkok dalam sengketa teritorial dan maritim di Laut Cina Selatan dan Laut Cina Timur juga telah mengubah jaringan keamanan wilayah tersebut. Artinya, kebangkitan Tiongkok yang disebabkan oleh pertumbuhan ekonomi yang melesat diterjemahkan ke dalam pengeluaran militer yang lebih besar dan yang paling penting, ke dalam modernisasi militer yang ditandai 
terutama dengan meningkatnya kemampuan proyeksi daya dan aspirasi angkatan lautnya. Sejak tahun 2000-an, kepentingan strategis Tiongkok telah melampaui Laut Cina, ketegangan hubungan dengan Taiwan dan semenanjung Korea. Secara historis, geopolitik Tiongkok terutama berfokus pada wilayah daratan. Sebagian besar sengketa teritorial mereka diselesaikan pada 1960-an dan 1990-an dan Tiongkok sekarang berfokus pada pengaruh maritimnya. Doktrin strategis baru Tentara Pembebasan Rakyat Tiongkok disusun berdasarkan keinginan untuk menjadikan Laut Cina Selatan sebagai laut Tiongkok dan untuk memperluas kepentingan maritim langsungnya. Angkatan Laut Tiongkok membenarkan diri pada negara tetangganya yang khawatir dengan kebangkitan negara tersebut dengan alasan perlunya mengawal kapal komersial yang penting bagi perekonomian negara; tetapi sudah diketahui secara umum bahwa prioritas strategi Tiongkok yang baru adalah menjadi operasional di luar Laut Cina dan Filipina (Milhiet 2017: 2).

Sebuah laporan tahun 2019 oleh Oxford Analytica, perusahaan penilai risiko global yang berbasis di Inggris, mengatakan Cina memiliki empat tujuan dalam memperluas jangkauannya ke Pasifik Selatan, yaitu, memperluas perimeter keamanannya ke wilayah yang sampai sekarang masih mempertahankan AS dan sekutu-sekutunya dan menciptakan penyangga antara Cina dan tetangganya. Kedua adalah kontes diplomatik dengan Taiwan- di mana dari 17 negara di dunia yang masih memiliki hubungan diplomatik penuh dengan Taiwan, enam di antaranya adalah negara-negara Kepulauan Pasifik, yaitu, Kepulauan Solomon, Palau, Nauru, Kiribati, Tuvalu, dan Kepulauan Marshall. Ketiga adalah untuk mendapatkan akses ke sumber daya alam Pasifik Selatan dan kepulauannya, terutama ikan dan kayu, di mana Tiongkok sudah menjadi mitra dagang terbesar untuk sebagian besar pulau dan memiliki sekitar \$30 miliar yang diinvestasikan di antara mereka. Keempat adalah untuk menarik negara-negara Pasifik Selatan ke Belt Road Initiative Beijing dengan menjual infrastruktur kepada mereka, khususnya fasilitas pelabuhan untuk memberi manfaat bagi perdagangan Tiongkok dan penyebaran jangka panjang angkatan lautnya (Manthrope 2019).

\subsection{Rumusan Masalah}

Tiongkok dan Taiwan telah menjadi aktor utama dalam hubungan di Pasifik Selatan, yang disebabkan terutama oleh kapasitas Kepulauan Pasifik untuk memberikan pengakuan diplomatik. Pertentangan kuat Tiongkok terhadap pencarian hubungan diplomatik oleh Taiwan mendorong sebagian besar negara menghitung bahwa mereka akan kehilangan lebih banyak secara politik dan ekonomi jika menentang Tiongkok daripada yang akan mereka dapatkan dari mengakui Taiwan. Pertimbangan ekonomi telah menjadi hal yang relatif biasa di dalam persaingan Taiwan dan Tiongkok, di mana ini lebih terkait dengan mempengaruhi negara Kepulauan Pasifik dan pembuat kebijakan daripada memajukan kepentingan ekonomi kedua negara tersebut-yang berbeda dengan misal Jepang yang kebijakannya di kawasan ini dipengaruhi oleh kepentingan ekonomi jangka pendek dan jangka panjang khususnya yang terkait dengan penangkapan ikan dan pariwisata. Namun Taiwan dapat membeli pengakuan diplomatik dari negara Kepulauan Pasifik yang tak acuh terhadap kekuatan Tiongkok. Tiongkok sendiri memberi insentif untuk menghentikan negara-negara tersebut dari mengakui Taiwan, menciptakan pasar untuk pengakuan diplomatik. Seiring dengan pertumbuhan ekonomi Tiongkok dan Taiwan, persaingan mereka meningkat karena sumber daya yang tersedia juga meningkat (Atkinson 2010: 408). Pertumbuhan ekonomi Tiongkok yang tumbuh relatif cepat dalam beberapa tahun terakhir telah mengintensifkan persaingan diplomatiknya dengan Taiwan, dan Tiongkok semakin mengungguli Taiwan di seluruh dunia (Dumbaugh 2008: 26). Selain itu, Tiongkok juga mampu mendukung diplomat-diplomat di Pasifik Selatan di negara mana pun, sebuah kumpulan tenaga kerja yang signifikan untuk memprioritaskan persaingan dengan Taiwan (Senat 2006: 163, 167). Namun, menurut Atkinson (2010: 410), 
meningkatnya tekanan Tiongkok ini tidak menjanjikan negara tersebut untuk memiliki kapasitas untuk mengalahkan Taiwan secara langsung. Semakin sedikit sekutu yang dimiliki Taiwan, semakin banyak yang dapat Taiwan tawarkan, dan semakin banyak dari sekutu Tiongkok yang mengharapkan lebih dari Tiongkok. Oleh karena itu, Tiongkok tidak mungkin dapat membeli semua sekutu Taiwan, dan dengan demikian, tidak mengherankan jika Taiwan dapat mempertahankan hubungan diplomatik di Pasifik Selatan hampir sama dengan di tahun 1980-an. Maka, pertanyaan yang akan dibahas dalam artikel ini adalah: Mengapa Kepulauan Solomon akhirnya mengalihkan dukungan diplomatiknya dari Taiwan ke Tiongkok setelah 36 tahun menjadi sekutu?

\section{Kajian Pustaka dan Kerangka Pemikiran}

Dalam teori hubungan internasional, terdapat debat yang sudah berlangsung lama tentang pentingnya balancing (bersekutu melawan negara yang memiliki peningkatan kekuatan) dan bandwagoning (bersekutu dengan negara yang memiliki peningkatan kekuatan, untuk mendapatkan keuntungan dari kemenangan yang diantisipasi). Menurut besarnya kekuatan yang dideskripsikan oleh Stephen Walt dan Kenneth Waltz, negara dengan pemimpin tidak sah, institusi pemerintah yang lemah, dan/atau kemampuan yang sedikit untuk memobilisasi sumber daya ekonomi adalah negara lemah yang hampir pasti akan melakukan bandwagoning. Definisi bandwagoning menurut Walt adalah:

"Bandwagoning involves unequal exchange; the vulnerable state makes asymmetrical concessions to the dominant power and accepts a subordinate role. . . . Bandwagoning is an accommodation to pressure (either latent or manifest). . . Most important of all, bandwagoning suggests a willingness to support or tolerate illegitimate actions by the dominant ally." (Walt 1988: 282)

Akademisi selama ini menganggap bahwa bandwagoning diimplikasikan dengan efek domino, namun pandangan mereka yang lebih menonjol adalah negara biasanya melakukan balancing, dan karena bias dalam status quo dalam analisis realis struktural mengarah pada interpretasi sempit bandwagoning sebagai perilaku yang berlawanan dengan balancing. Schweller (1994: 74) berpendapat bahwa ini adalah dikotomi yang salah: bandwagoning bukanlah kebalikan dari balancing. Keduanya termotivasi oleh kepentingan negara akan keamanan, teteapi bandwagoning dipandang sebagai strategi yang menyerah pada ancaman daripada menghalangi ancaman tersebut. Schweller mengatakan bahwa tujuan balancing adalah pelestarian diri nilai-nilai yang dimiliki, sedangkan tujuan bandwagoning biasanya self-extension: untuk mendapatkan nilai-nilai yang didambakan, yang bisa saja didasarkan pada keserakahan dan tidak memerlukan ancaman sama sekali.

Bandwagoning dapat memiliki berbagai motivasi, di mana kekuatan yang puas akan bergabung dengan koalisi status quo, bahkan ketika itu adalah sisi yang lebih kuat; kekuatan yang tidak puas dan termotivasi oleh keuntungan daripada oleh keamanan, akan melakukan bandwagoning dengan negara revisionis yang sedang bangkit (Schweller 1994: 88). Schweller memperluas proposisi ini dengan membagi bandwagoning ke beberapa jenis, yaitu jackal bandwagoning, piling on, wave of the future, dan the contagion or domino effect; dan jenis negara yang melakukan bandwagoning, yaitu lions, lambs, jackals, dan wolves. 
Gambar 1. Jenis-jenis bandwag oning menurut Scwheller

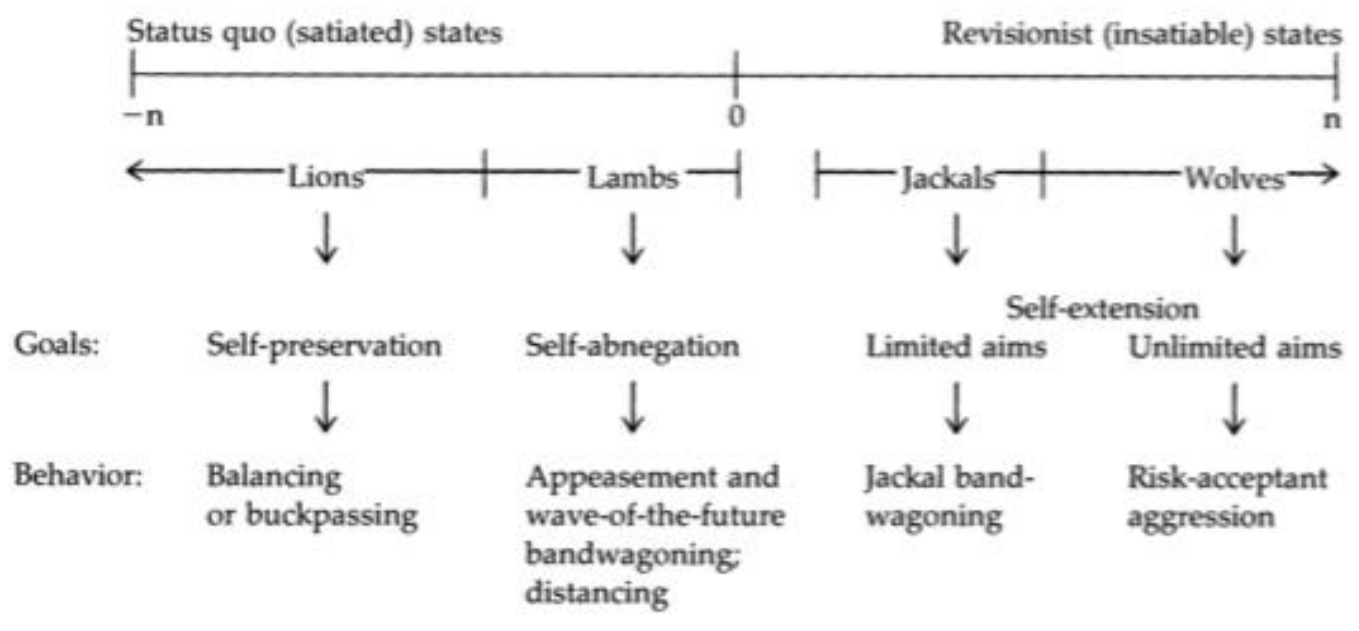

NOTE: The top line represents the state's calculation of its relative interests in the values of revision and of the status quo. Where the status quo outweighs revision (where $\mathrm{n}$ is negative), states are satiated; where revision outweighs the status quo (n is positive), states are revisionist.

Dalam jurnal ini, penulis beranggapan bahwa Kepulauan Solomon melakukan bandwagoning jenis wave of the future di mana "negara melakukan bandwagon dengan pihak yang lebih kuat karena mereka percaya pihak tersebut merepresentasikan masa depan" (Schweller 1994: 96) dan menjadi negara jenis lamb terhadap Tiongkok karena "negara lamb (domba) adalah negara yang akan membayar lebih rendah untuk mempertahankan atau memperluas nilai-nilai mereka... negara domba adalah negara yang lemah" (Schweller 1994: 101-102).

\section{Metode Penelitian}

Penulisan dalam jurnal ini menggunakan pendekatan kualitatif. Penelitian kualitatif dapat diartikan sebagai metode penelitian yang tidak mengandalkan proses kuantifikasi data baik dalam proses pengumpulan data maupun dalam proses analisis data. Menurut Alan Bryman (2004: 366), penelitian kualitatif tidak dilakukan dengan cara menghitung atau mengukur data statistik untuk menjelaskan keterkaitan sebuah hal dengan hal lain tetapi penelitian kualitatif lebih menitik beratkan pada pemaknaan dalam bentuk kata-kata yang bisa memberi gambaran dan/atau penjelasan atas sebuah keadaan yang menjadi fokus penelitian. Metode penelitian kualitatif menekankan pada deskripsi konteks karena bahasan detail sangat penting dalam menunjukkan signifikansi subjek penelitian dan menyedian penejelasan tentang konteks di mana suatu kejadian yang menjadi fokus penelitian terjadi.

\section{Hasil dan Pembahasan}

\subsection{Persaingan Tiongkok dan Taiwan}

Pada tahun 1949, di akhir perang sipil Tiongkok yang berkepanjangan, pasukan nasionalis anti-komunis menarik diri ke Taiwan. Mereka mendapatkan dukungan Amerika 
Serikat dan sekutunya dengan klaim mereka sebagai pemerintah Tiongkok yang sah hingga tahun 1972, ketika terjadi kunjungan presiden AS saat itu Richard Nixon ke Tiongkok yang menggarisbawahi perubahan besar dalam kebijakan AS. Tiongkok (People's Republic of China) diakui oleh AS (dan oleh Australia dan Selandia Baru) sebagai pemerintah Tiongkok yang sah, sementara Taiwan tetap diberi dukungan militer AS untuk statusnya yang terpisah. Sejak awal 1970-an Taiwan telah berjuang untuk mendapatkan pengakuan diplomatik, dan mendapatkan kembali keanggotaan PBB yang hilang pada tahun 1971. Sebaliknya, Tiongkok telah berupaya mengisolasi Taiwan secara diplomatis. Dalam pandangan Tiongkok, Taiwan merupakan provinsi yang membangkang yang tetap menjadi bagian integral dari Tiongkok, dan Tiongkok merupakan satu-satunya pemerintah seluruh Tiongkok karena negara tersebut sepenuhnya menolak gagasan "two Chinas".

Kursi permanen dan hak veto yang dialokasikan ke Tiongkok di Dewan Keamanan PBB adalah salah satu faktor penentu dalam kompetisi kedua negara tersebut pada tahun 1960-an hingga 1980-an. Ketika Taiwan menduduki kursi tersebut, ia membantu negosiasi pemimpin Nauru Hammer DeRoburt dalam PBB tentang penghentian perjanjian perwakilan menjelang kemerdekaan Nauru pada 1968. Nauru kemudian menjalin hubungan dengan Taiwan pada tahun 1980 sebagai bentuk terima kasih. Namun banyak negara-negara Kepulauan Pasifik yang merdeka setelah Tiongkok mengambil kursi DK PBB tersebut. Sebagai contoh, dokumen pemerintah Australia menyiratkan adanya pengaruh Tiongkok di PBB membantunya membangun hubungan diplomatik eksklusif dengan Papua Nugini. Tiongkok juga menggunakan dukungannya untuk kemerdekaan Vanuatu untuk mempengaruhi keputusan negara tersebut mengakui Tiongkok (Zamiska dan Dean 2006). Tiongkok dan Taiwan telah memberikan perhatian khusus pada kawasan Pasifik Selatan sebagai arena kompetisi diplomatik, memberikan dampak terhadap hubungan di wilayah tersebut. Ciri unik dari negara kepulauan Pasifik Selatan, termasuk status mereka sebagai negara kecil dan mikro yang sebagian besar bergantung pada bantuan asing, telah memberikan peluang bagi inisiatif diplomatik yang efektif biaya oleh rezim Tiongkok. Inisiatif ini diarahkan terutama pada para pemimpin politik yang muncul dan melibatkan komunitas etnis Tionghoa (Biddick 1989: 801). Persaingan antara Tiongkok dan Taiwan telah menciptakan manfaat dan masalah bagi negara-negara yang baru merdeka. Penduduk pulau diuntungkan sebagai penerima perhatian politik dan bantuan ekonomi. Namun pada saat yang bersamaan, masalah "two Chinas" telah memberi mereka dilema ketika para pemimpin Forum Pasifik Selatan menghadapi pertanyaan tentang memperluas dialog tahunan mereka untuk melibatkan pihak luar.

Upaya Taiwan untuk mendapatkan pengakuan internasional telah menikmati beberapa keberhasilan. Pada awal 2000 ada 29 negara-terutama negara kecil dari Karibia, Amerika Tengah, Afrika dan Pasifik-yang mengakui Taiwan, sebuah peningkatan dibandingkan dengan pengakuan oleh 24 negara pada tahun 1989 (Biddick, 1989: 811). Pada tahun 2000 terdapat lima negara di Pasifik Selatan yang berpihak pada Taiwan, yaitu Kepulauan Solomon, Nauru, Palau, Kepulauan Marshall, dan Tuvalu, walaupun Kepulauan Solomon sempat menimbang untuk menarik dukungannya. Pada pertengahan 1999, Papua Nugini secara singkat mengalihkan dukungan diplomatiknya dari Tiongkok ke Taiwan, sebelum pemerintah baru membalikkan keputusan dan menegaskan kembali hubungan diplomatik dengan Tiongkok. Pada tahun 2018, pengakuan diplomatik dari seluruh negara di dunia terhadap Taiwan turun menjadi 18 dengan enam negara Pasifik Selatan yang mendukung Taiwan secara diplomatik, yaitu Kiribati, Marshall Islands, Nauru, Palau, Kepulauan Solomon, dan Tuvalu. Tahun 2019, jumlah tersebut turun menjadi hanya 14 negara dan Vatikan; tersisa hanya empat negara Pasifik Selatan dengan Kiribati sebagai negara terbaru yang memutus hubungan diplomatik dengan Taiwan pada September 2019 setelah Kepulauan Solomon. 


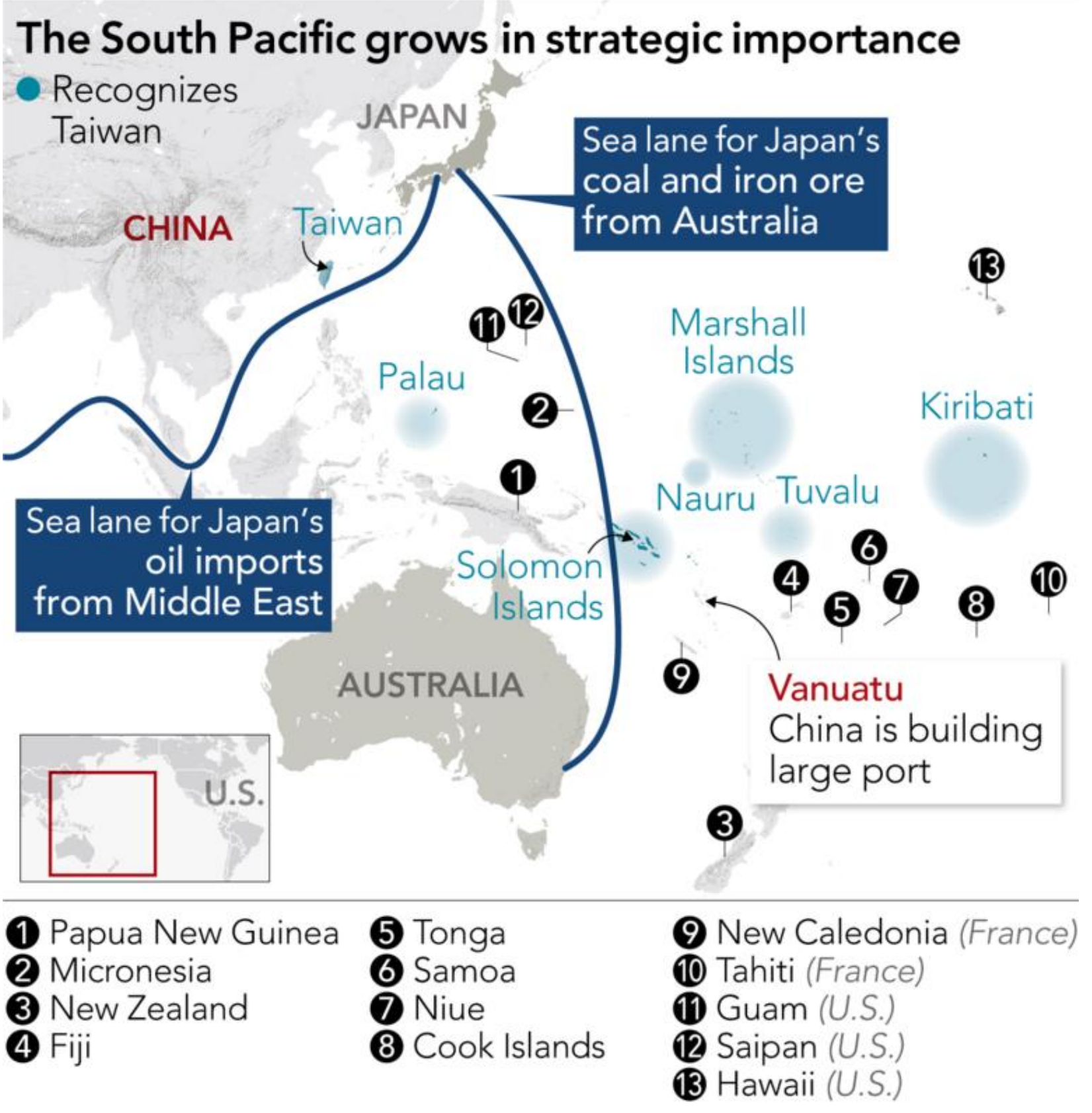

Sumber: Asia Nikkei

Kepulauan Solomon, yang secara strategis terletak di Pasifik Selatan, merupakan negara terbesar dari enam negara ketika Taiwan masih memiliki hubungan di kawasan Asia Pasifik. Pemutusan diplomatik Kepulauan Solomon ini memiliki implikasi dengan negaranegara tetangganya. Terletak sekitar 1.750 kilometer timur laut Cairns, di utara Australia, negara tersebut bergabung dengan Papua Nugini, Vanuatu, Fiji dan Tonga-yang terletak pada poros dengan Kepulauan Solomon dan telah memiliki hubungan diplomatik resmi dengan Tiongkok. Dengan Kepulauan Solomon dan Kiribati di orbit Tiongkok, akses Australia ke kawasan Asia Pasifik secara geografis terhambat oleh blok pro-Beijing. Hambatan ini tidak terbantu oleh Indonesia di utara, negara lain yang memiliki hubungan 
ekonomi yang erat dengan Tiongkok. Perubahan diplomatik terbaru ini adalah taktik strategis Tiongkok untuk membentuk "tembok besar" di utara dan barat Australia (Akita 2019). Di Vanuatu, Tiongkok sedang membangun pelabuhan besar, dengan pengamat berspekulasi bahwa fasilitas tersebut akan digunakan sebagai pangkalan militer. Tahun lalu, Tiongkok memberi Fiji kapal perang, sementara di Papua Nugini, pelabuhan dan jalan sedang dibangun dengan dukungan Tiongkok. Tiongkok sendiri telah menyatakan niat untuk melakukan militerisasi Belt Road Initiative (BRI) untuk memperkuat hubungan dengan negara-negara Pasifik Selatan, yang merupakan tantangan signifikan terhadap lingkungan strategis Asutralia. Pada pertemuan kepala militer dari negara-negara Pasifik Selatan dan Karibia di Beijing pada Juli 2019, Menteri Pertahanan Tiongkok Wei Fenghe mengatakan bahwa BRI akan memberikan kerangka kerja untuk kerja sama militer yang lebih besar, yang merupakan kebalikan dari apa yang selama ini diserukan oleh rezim negara tersebut sebagai hanya kendaraan bagi pembangunan ekonomi yang damai.

Hingga saat ini, Tiongkok telah berhasil mendirikan kedutaan besar di Papua Nugini, Fiji, Samoa, Vanuatu, Kiribati, Tonga, Mikronesia, Kepulauan Cook, dan Niue. Taiwan sendiri menghadapi tekanan ekonomi dan diplomatik yang semakin intensif dari Tiongkok sejak pemilihan presiden 2016, Tsai Ing-wen, setelah secara tegas menolak kebijakan "one China policy", yang mengakui keberadaan Taiwan di bawah pemerintah Tiongkok. Bulan lalu, Forum Kerjasama Ekonomi dan Pembangunan Negara-Negara Pulau Tiongkok-Pasifik Ketiga diadakan di Apia, Samoa dihadiri oleh Wakil Perdana Menteri Hu Chunhua. Pada bulan yang sama, Presiden Xi Jinping dan Perdana Menteri Li Keqiang bertemu dengan Perdana Menteri Kepulauan Solomon Manasseh Sogavare di Beijing. Xi juga bertemu dengan mantan Perdana Menteri Selandia Baru John Key di Beijing. Pada bulan September, Anggota Dewan Negara dan Menteri Luar Negeri Wang Yi bertemu dengan Menteri Luar Negeri Australia Marise Payne di sela-sela Majelis Umum PBB di New York, sebuah pertemuan di saat tensi hubungan bilateral yang kian tinggi (Pitio 2019).

\subsection{Motif Pengalihan Dukungan Diplomatik}

Hal-hal yang mendorong Kepulauan Solomon melakukan pengalihan dukungan diplomatik dari Taiwan ke Tiongkok dapat dilihat dari laporan yang dihasilkan oleh task force atau satuan tugas Bi-Partisan Kepulauan Solomon, pemain kunci yang ditunjuk oleh Perdana Menteri Manasseh Sogavare pada Juni 2019 untuk meninjau kembali hubungan negara tersebut dengan Tiongkok dan Taiwan, dan pernyataan oleh Sogavare tentang pengalihan diplomatik ini, mengungkapkan banyak tentang persepsi lokal terhadap kebangkitan China dan perubahan geopolitik di wilayah tersebut. Satuan tugas tersebut terdiri dari sembilan anggota, termasuk tujuh anggota parlemen (tiga dari pemerintah, tiga dari oposisi, dan satu anggota independen) dan dua staf sekretariat dari Kantor Perdana Menteri dan Kabinet. Setelah berkonsultasi dengan pejabat dan pemangku kepentingan dari negara-negara termasuk Fiji, Papua Nugini, Samoa, Tonga, Vanuatu, Tiongkok dan Taiwan, tim merekomendasikan agar Kepulauan Solomon memutuskan hubungan diplomatik dengan Taiwan dan menormalisasikan hubungan dengan China selambat-lambatnya sebelum perayaan ulang tahun ke-70 RRC pada tanggal 1 Oktober 2019. Dalam jurnal ini motif pengalihan dukungan diplomatik yang dilakukan oleh Kepulauan Solomon akan dibagi menjadi dua, yaitu keuntungan ekonomi dan geopolitik.

\subsubsection{Keuntungan Ekonomi}

Tiongkok dan Taiwan menolak untuk sepenuhnya mengungkapkan apa yang mereka berikan pada sekutu mereka di Pasifik Selatan. Hal ini supaya dapat mencegah negara-negara 
yang menjual pengakuan diplomatik untuk menggelembungkan tuntutan mereka sesuai dengan jumlah yang diterima negara lain (Atkinson 2010). Tumbuhnya bantuan, perdagangan, dan penjangkauan diplomatik dan rumor kepentingan dalam mengamankan pangkalan-pangkalan meningkatkan kekhawatiran tentang perluasan jejak Tiongkok di Pasifik. Namun walaupun negara-negara kepulauan Pasifik tidak naif akan tumbuhnya persaingan kekuatan besar, mereka tidak serta-merta memiliki tingkat kekhawatiran yang sama dengan yang dimiliki oleh kekuatan lama Oseania. Beberapa bahkan menyambut kedatangan Tiongkok sebagai cara untuk memaksa kekuatan tradisional Pasifik untuk berkomitmen kembali ke wilayah tersebut. Dari 2011 hingga 2019, Cina memberikan $\$ 1,47$ miliar pinjaman kepada negara-negara kepulauan Pasifik. Jika Tiongkok membayar sesuai dengan janjinya, ia kemungkinan akan menyalip Australia untuk menjadi penyumbang terbesar di kawasan tersebut (Pitio 2019).

Gambar 3. Jumlah pinjaman dan bantuan Tiongkok ke negara Pasifik Selatan 2011-18

\section{Chinese loans and aid}

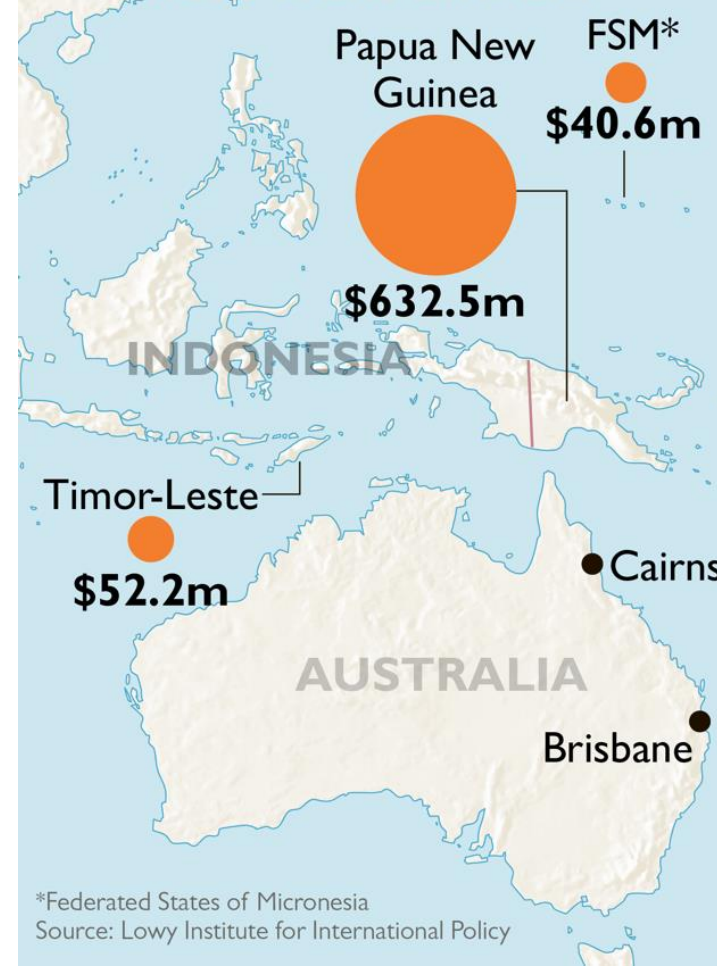

$\$ 1.78 \mathrm{bn}$

Total

committed

aid

id

Pacific Ocean

\section{(n)}


mendukung pertumbuhan ekonomi di negara tersebut. Menurut data World Bank, hal ini penting bagi Kepulauan Solomon karena infrastruktur yang buruk dianggap sebagai hambatan terbesar di negara itu, karena sangat menghambat pembangunannya meskipun memiliki sumber daya yang kaya akan mineral, kehutanan dan perikanan. Selama 36 tahun antara tahun 1983 dan 2019, Taiwan telah memberikan total \$460 juta bantuan untuk Kepulauan Solomon. Untuk mendapatkan dukungan bagi hubungan diplomatik, sebagian besar bantuan Taiwan diberikan kepada Rural Constituency Development Fund atau Dana Pembangunan Pedesaan, yang menikmati popularitas di kalangan anggota parlemen karena penggunaannya sesuai dengan kebijaksanaan mereka, tetapi mengundang kritik yang lebih luas untuk membiakkan korupsi. Taiwan juga memberikan bantuan teknis untuk sektor-sektor seperti pertanian dan kesehatan di Kepulauan Solomon. Namun, masih terdapat kesenjangan dalam pendanaan infrastruktur. Perdana Menteri Sogavare juga mengeluh bahwa para investor Taiwan kurang menunjukkan minat untuk berinvestasi dalam pembangunan ekonomi dibandingkan dengan kepentingan politik di negaranya selama 36 tahun terakhir (Sograve 2019).

Selain itu, Kepulauan Solomon juga mempercayai janji-janji Tiongkok dalam perdagangan, bantuan dan daya tarik investasi kepada pemerintah Kepulauan Solomon, terutama dalam infrastruktur. Setelah bertemu dengan para diplomat senior China dan perwakilan dari perusahaan-perusahaan besar Tiongkok yang beroperasi di Pasifik seperti China Civil Engineering Construction Corporation, China Harbour Engineering Corporation dan Huawei, satuan tugas tersebut menyimpulkan bahwa Kepulauan Solomon akan mendapat banyak keuntungan jika beralih dan menormalkan hubungan diplomatik dengan Tiongkok. Perdana Menteri Sogavare menyatakan bahwa ia percaya bahwa dengan menjalin hubungan diplomatik dengan RRC dapat membantu negara mencapai beberapa aspirasi pembangunannya,

"We believe that being friend to all, enemy to none, gives us room to make more friends, and we believe that by establishing diplomatic tie with PRC can assist the country achieve some of its development aspirations. Ease of doing business directly with China rather than passing through middlemen will be greatly enhanced. The cost of doing business with China who is our single major trading partner will become cheaper and more efficient." (Sograve 2019)

Tiongkok juga meyakinkan Kepulauan Solomon bahwa mereka akan memberikan bantuan untuk mengisi kesenjangan yang ditinggalkan oleh Taiwan dalam masa transisi, termasuk untuk mengambil siswa Kepulauan Solomon yang sedang belajar di Taiwan dan mendanai stadion South Pacific Games 2023. Secara khusus, pemerintah Kepulauan Solomon tertarik dengan Belt and Road Initiative (BRI) yang saat ini menjangkar kerja sama bilateral China dengan Pasifik terutama dalam bidang infrastruktur. Kepulauan Solomon mendaftar ke BRI selama kunjungan Sogavare ke Beijing pada Oktober 2019, menyelaraskan inisiatif Tiongkok dengan Strategi Pembangunan Nasional Kepulauan Solomon 2016-2030. Satuan tugas memiliki harapan tinggi pada BRI, dengan alasan bahwa inisiatif Beijing tersebut menjadi satu-satunya cara untuk menyelesaikan masalah pembangunan nasional yang terkendala infrastruktur,

"The BRI can help Solomon Island to implement its National Development Strategic plans 2016-2030. Currently, only China has such an initiative for its bilateral friends. None of our traditional partners has its equivalent... This, China initiative, holds the only means to solve this national development issue as it has done for other countries, including countries in the Pacific region." (Bi-Partisan Task Force 2019: 38-39) 
Satuan tugas Bi-Partisan menyebut dukungan sektoral yang akan Tiongkok berikan untuk Kepulauan Solomon mencakup Constituency Development Fund (CDF), beasiswa pemerintah, olahraga, perdagangan, pasar, investasi, infrastruktur, pertanian, pariwisata, perikanan dan mineral.

Hubungan perdagangan bilateral yang kuat antara Tiongkok dan Kepulauan Solomon juga digarisbawahi oleh satuan tugas dan Sogavare untuk mendukung peralihan tersebut. Tiongkok adalah mitra dagang Kepulauan Solomon terbesar dengan volume perdagangan 14 kali lipat dari Taiwan. Menurut Bank Dunia, pada tahun 2017, Kepulauan Solomon mengekspor komoditas senilai \$ 554,8 juta, atau dua pertiga dari total ekspornya, ke Tiongkok dan 87 persen merupakan produk kayu. Faktor lain yang disebutkan oleh satuan tugas adalah hubungan orang-ke-orang yang kuat yang didukung oleh diaspora Tiongkok (sekitar 3.000) di Kepulauan Solomon yang telah aktif dalam ekonomi lokal terutama di sektor ritel. Walaupun berkontribusi pada ekonomi lokal, beberapa orang Tiongkok dibenci oleh penduduk Kepulauan Solomon karena terlibat dalam kasus suap, menjual produk-produk di bawah standar, pelanggaran bea cukai dan ketidakmampuan untuk berintegrasi dengan masyarakat lokal. Ini membuat mereka menjadi sasaran empuk selama kerusuhan sosial seperti pada kerusuhan tahun 2006. Kasus kerusuhan 2006 timbul karena ketidakpuasan pada pemilihan politisi lama ke posisi perdana menteri, dan karena bisnis Asia (Tiongkok) mendominasi industri penebangan, pertambangan dan perikanan, dominasi mereka terhadap industriritel di Honiara memberikan target simbolis untuk menandakan perbedaan pendapat atas kontrol politik dan kontrol asing terhadap pembangunan. Maka terjadi penargetan bisnis Asia baru di Chinatown (bisnis mapan yang telah berada di Kepulauan Solomon selama beberapa dekade dan memiliki hubungan yang lebih mengakar dengan masyarakat setempat terhindar dari penjarahan dan perusakan properti). Dalam konteks ini, membangun hubungan diplomatik dengan Tiongkok dapat memberikan peluang bagi Kepulauan Solomon, dalam kemitraan dengan Tiongkok, untuk mengatur kegiatan bisnis Tiongkok di negara Pasifik dan memperkuat hukum pelaksanaan perdagangan.

Secara umum satuan tugas menggambarkan gambaran indah hubungan Cina-Pasifik dan keuntungan potensial bagi Kepulauan Solomon. Namun, ia juga memperingatkan secara singkat bahwa Kepulauan Solomon perlu mengembangkan kebijakan "keterlibatan strategis" dengan Tiongkok. Satuan tugas menyoroti pentingnya bagi pemerintah Kepulauan Solomon untuk mengelola hubungan baru dengan China dengan baik, yakni dengan cara mengatur mekanisme dan kerangka kerja, dan memiliki para profesional dan ahli yang memenuhi syarat untuk mengelola hubungan ini. Satuan tugas juga menunjukkan minat untuk belajar dari negara-negara Pulau Pasifik lainnya seperti Fiji dan Vanuatu dalam berurusan dengan Tiongkok dalam berbagai cara, seperti mengembangkan hubungan baik dengan kekuatan Barat dan juga Tiongkok; mengelola utang eksternal dan melindungi kepemilikan tanah lokal; dan memiliki hukum dan peraturan (terkait dengan investasi, imigrasi, tanah, dan tenaga kerja) untuk mengakomodasi masuknya bantuan dan investasi Tiongkok. Amerika Serikat memiliki pengaruh besar di tiga negara bagian terkait Kepulauan Marshall, Negara Federasi Mikronesia, dan Palau, tetapi pengaruhnya di negara-negara Pulau Pasifik lainnya terbatasi. Satuan tugas Bi-Partisan kritis terhadap Amerika Serikat karena fokusnya lebih pada masalah diplomatik dan keamanan daripada pembangunan ekonomi di Pasifik termasuk di Kepulauan Solomon. Ia mengklaim bahwa Amerika Serikat mendukung Kepulauan Solomon dalam meninjau kembali hubungannya dengan Tiongkok dan Taiwan dan menyebut bahwa "kemungkinan tidak ada reaksi balik jika kita beralih," yang terbukti salah. Pemerintah AS menentang peralihan Kepulauan Solomon ke Cina, yang tidak disukai oleh Perdana Menteri Sogavare dalam pernyataannya. Ini mungkin mengapa satuan tugas menambahkan bahwa akan ada beberapa dampak pada Kepulauan Solomon yang merupakan reaksi dari pendonor tradisional sebagai akibat dari peralihan, dan karenanya tetap dibutuhkan peninjauan dan 
peningkatan keterlibatan Kepulauan dengan para pendonor tradisional tersebut. Hubungan yang lebih dekat dengan Tiongkok dapat meningkatkan daya tawar Kepulauan Solomon dalam berurusan dengan kekuatan tradisional, tetapi akan membawa banyak tekanan dari mereka.

\subsubsection{Geopolitik}

Satuan Tugas Bi-Partisan menjelaskan tentang geopolitik di Pasifik Selatan yang berkaitan dengan kepentingan Amerika Serikat di kawasan Indo-Pasifik berputar di sekitar hegemonnya. Untuk mempertahankan hegemon tersebut maka Amerika Serikat harus memiliki kendali ekonomi dan militer. Ini menjelaskan perang dagang AS-Cina saat ini dan peningkatan militer AS di kawasan ini. Taiwan telah dan akan selalu menjadi pion AS dalam persaingannya dengan Tiongkok. Oleh karena itu, Taiwan kemungkinan tidak diizinkan memiliki independensi penuh. Kecil kemungkinan bahwa AS akan mengizinkan Taiwan menjadi negara merdeka, karena kepentingan AS bagi Taiwan adalah untuk mempertahankan status quo untuk tujuan memecah belah dan memerintah. AS menganggap Taiwan sebagai rantai pulau pertama untuk penahanan Tiongkok, yang kemudian menjadi salah satu alasan AS tetap menjual senjata ke Taiwan (Bi-Partisan Task Force 2019: 10). Pada akhir 2017, di bawah pemerintahan Presiden Trump, diumumkan adanya penjualan senjata senilai $\$ 1,42$ miliar ke Taiwan, yang merupakan kontradiksi terhadap kesepakatan konsensus yang dicapai antara Presiden Xi Jingping dan Trump pada bulan April di tahun yang sama. Pada tahun 2018, pemerintah AS menyetujui penjualan lebih lanjut suku cadang jet tempur F-16 ke Taiwan senilai $\$ 330$ juta. Pada 2019, kesepakatan senjata lebih lanjut senilai $\$ 500$ juta ditandatangani antara AS dan Taiwan.

Di sisi lain, satuan tugas Bi-Partisan menganggap bahwa Tiongkok tidak mengejar ekspansi militer, sehingga keterlibatannya dalam keamanan terbatas, dibandingkan dengan keterlibatan diplomatik dan ekonominya. Oleh karena itu, Kepulauan Solomon mengambil keputusan bukan hanya karena sebatas Tiongkok dan Taiwan, namun ini adalah keputusan yang diambil dalam konteks saling ketergantungan regional dan internasional yang kompleks, seperti disebutkan dalam laporan,

"the choice that Solomon Islands comtemplates is not simply between

$P R C$ and ROC. It is a decision taken within the context of complex

regional and international interdependence. The government of Solomon

Islands must, therefore, redefine itself in terms of its status as an 'Island

State' within a global context." (Bi-Partisan Task Force 2019: 15)

Kepulauan Solomon selama ini didefinisikan oleh statusnya sebagai negara pulau, yang oleh karena itu dipengaruhi oleh agenda kepentingan dan kekuatan negara besar. Tiongkok dianggap sebagai kekuatan besar yang masuknya ke wilyah Pasifik Selatan telah menimbulkan tantangan langsung terhadap dominasi Australia dan Selandia Baru, sebagai kekuatan proxy Amerika Serikat. Oleh karena itu, Kepulauan Solomon harus mengikuti dinamika transisi kekuasaan di wilayah tersebut sehingga dapat mengambil manfaat ari dinamika kekuatan baru ini.

Kepulauan Solomon biasanya mengandalkan dan mengikuti kekuatan besar, dalam hal ini secara tradisional negara tersebut bergantung pada Amerika Serikat dan negara-negara proxy seperti Australia dan Selandia Baru sebagai penjamin pembangunan, ekonomi, dan keamanan negara. Namun, dalam beberapa dekade terakhir, terlihat jelas ada pergantian kekuasaan di Asia Pasifik, di mana hegemoni Amerika Serikat yang sudah berlangsung selama berpuluh tahun ditantang oleh kebangkitan Tiongkok dan prospek perkembangan negara-negara Asia Timur dan Tenggara dengan Tiongkok sebagai jantung dari semua 
perkembangan di wilayah tersebut. Oleh karena itu, Kepulauan Solomon merasa perlu meninjau kembali keberpihakannya dalam dinamika saat ini. Dalam pandangan kolektivisme, yang melibatkan koalisi negara-negara kepulauan melalui lembaga seperti Pacific Islands Forums (PIF) atau Melanesian Spearhead Group (MSG), Kepulauan Solomon juga merasa harus berdiri dalam solidaritas dengan negara-negara tetangganya untuk menggunakan suara dan kekuasaan bersama. Seperti yang ditulis oleh anggota parlemen Vanuatu Johnny Koanapo pada September 2019 bahwa, "vakum hanya menawarkan kesempatan bagi orang lain untuk mengisinya," dalam menanggapi pernyataan Duta Besar Amerika Serikat untuk Papua Nugini, Kepulauan Solomon dan Vanuatu Catherine Ebert-Gray bahwa pemerintahnya "sangat kecewa" dengan keputusan pemerintah Kepulauan Solomon untuk mengalihkan hubungan diplomatiknya dari Taiwan ke Tiongkok. Komentar Koanapo dianggap menggemakan sentimen yang dipegang secara luas di Pasifik Selatan.

"This choice has been simmering for several years and if our friends thought that the signal wasn't strong or important enough then it means there has either been too much ignorance or nobody just cared." (Koanapo 2019)

Menurutnya, pengalihan dukungan ini merupakan keputusan yang tidak dapat dihindari oleh Kepulauan Solomon karena tidak ada jaminan dari Amerika Serikat atau mitra lain yang cukup untuk meyakinkan mereka bahwa Tiongkok tidak akan menjadi kehadiran ekonomi dan politik yang semakin dominan di masa mendatang.

\section{Kesimpulan dan Rekomendasi}

Pasifik Selatan merupakan wilayah yang strategis untuk kekuatan Barat (Amerika Serikat, Australia, Selandia Baru) melalui proxy Taiwan dan Tiongkok sehingga membuat wilayah tersebut menjadi panggung persaingan pengaruh antara kedua pihak untuk melancarkan kepentingan keamanan dan ekonomi masing-masing. Tiongkok dan Taiwan tetap akan menjadi dua sisi yang tidak menyatu di Pasifik Selatan dengan berkompetisi mendapatkan pengakuan diplomatik dari negara-negara di daerah tersebut melalui cara pragmatis yaitu penyediaan bantuan keuangan untuk pembangunan negara-negara Kepulauan Pasifik.

Kepulauan Solomon dan Tiongkok sedang memasuki periode bulan madu, di mana kedua negara akan membuka kedutaan besar di Beijing dan Honiara dan bantuan Tiongkok akan mulai mengalir masuk. Untuk pertama kalinya, Kepulauan Solomon akan bergabung dengan sembilan negara Kepulauan Pasifik lainnya (termasuk Kiribati) yang mengakui Tiongkok dengan menghadiri konferensi ketiga Forum Kerjasama Ekonomi dan Kerjasama Ekonomi Kepulauan Tiongkok-Pasifik di Apia pada Oktober lalu, dan dapatkan manfaat dari paket bantuan baru dalam kerangka BRI. Dalam jangka panjang, terdapat dua tantangan utama dalam hubungan ini, yaitu untuk mengelola hubungan dengan Tiongkok dengan baik, seperti yang disarankan oleh satuan tugas. Tantangan internal di Kepulauan Solomon sudah sangat besar, seperti kapasitas kelembagaan yang lemah dan korupsi, dan perlu dikelola sambil menavigasi hubungan baru dengan Tiongkok. Tantangan lain terkait dengan meningkatnya persaingan strategis antara Tiongkok dan Amerika Serikat di kawasan IndoPasifik, yang memunculkan pertanyaan apakah pemerintah Kepulauan Solomon mampu mengembangkan hubungan baik dengan kedua kekuatan super tersebut agar kepentingan nasionalnya tidak tergerus dan dapat terus memaksimalkan keuntungan untuk pembangunan ekonominya beserta infrastrukturnya. 


\section{DAFTAR PUSTAKA}

\section{Buku}

Brady, Anne-Marie ed. 2010. "Looking North, Looking South: China, Taiwan, and the South Pacific." Series on Contemporary China - Vol. 26. World Scientific Publishing Company.

Waltz, Stephen M. "Testing Theories of Alliance Formation: The Case of Southeast Asia." International Organization, Vol. 42, No. 2, pp. 275-316.

\section{Jurnal}

Atkinson, Joel. 2010. China-Taiwan and the Pacific Islands, The Pacific Review, 23:4, 407427. Routledge: Taylor and Francis Group.

Biddick, Thomas V. 1989. "Diplomatic Rivalry in the South Pacific: The PRC and Taiwan." Asian Survey, vol xxixx no 8, pp. 800-815.

Bi-Partisan Task-Force. 2019. Report of the Bi-Partisan Task-Force, Review of Solomon Islands Relations with People's Republic of China and Republic of China.

Honiara: Office of the Prime Minister and Cabinet. Diakses pada 20 Oktober 2019. shorturl.at/eUVZ7.

Dumbaugh, K. 2008. 'China's foreign policy: what does it mean for U.S. global interests?', Congressional Research Service Report for Congress RL34588, 18 Juli.

Diakses pada 16 Oktober 2019. http//fas.org/sgp/crs/row/RL34588.pdf

Firth, Stewart. 2018. "Instability in the Pacific Islands: A status report." Lowy Institute.

Fraenkel, Jon. 2008. The dangers of political party strengthening legislation in Solomon

Islands. Pacific Economic Bulletin, Vol. 23 No. 3. The Australian National University.

Henderson, John. 2001. China, Taiwan and the Changing Strategic Significance of Oceania. Diakses pada 21 Oktober 2019. doi:10.1.1.476.1675.

Milhiet, Paco. 2017. "China's Ambition in the Pacific: Worldwide Geopolitical Issues," Asia Focus \#49-Asia Program. Paris: Insitut Catholique de Paris.

McElroy, Jerome L dan Wenwen Bai. 2008. The Political Economy of China's Incursion into the Caribbean and Pacific. Canada: Institute of Island Studies.

Senate - Foreign Affairs, Defence and Trade References Committee. 2006. China's Emergence: Implications for Australia. Canberra: Commonwealth of $\begin{array}{lllll}\text { Australia. Diakses } & \text { pada } & 16 & \text { Oktober }\end{array}$ http:/www.comw.org/cmp/fulltext/0603chinareport. pdf.

Schweller, Randall L. 1994. "Bandwagoning for Profit: Bringing the Revisionist State Back In," International Security 19:1, pp. 72-107.

Zhang, Denghua. 2017. "China's Diplomacy in the Pacific Interests, Means and Implications," Security Challenges, Vol. 13, No. 2, pp. 32-53. Institute for Regional Security.

\section{Website}


Akita, Hiroyuki. 2019. "South Pacific pivot to Beijing recasts regional chessboard." Asia Nikkei, 22 September. Diakses pada 24 Oktober 2019. https://asia.nikkei.com/Spotlight/Comment/South-Pacific-pivot-to-Beijingrecasts- regional-chessboard

Jash, Amrita. 2017. "China, United States and the Changing Balance of Power in the Asia Pacific." East Asia Research Program. Diakses pada 21 Oktober 2019. http://earp.in/en/china-united-states-and-the-changing-balance-of-power-inthe-asia- pacific/.

Manthrope, Jonathan. 2019. "China targeting Pacific Isles for strategic bases." Asia Times, 8 $\begin{array}{lllll}\text { Juni. Diakses } & \text { pada } & 19 & \text { Oktober } & \end{array}$ https://www.asiatimes.com/2019/06/article/china- targeting-pacific-isles-forstrategic-bases/.

McGarry, Dan. 2019. "China-Taiwan: Solomon Islands' switch and a "new normal"." The Diplomat, 19 September. Diakses pada 21 Oktober 2019. http://lowyinstitute.org/the- interpreter/solomon- is land-s-switch-and-new-normal.

Pitio, Lucio Blanco. 2019. "China's Pacific Challenge." The Diplomat, 15 November. Diakses pada 17 November 2019. https $/ /$ thediplomat.com/2019/11/chinas-pacificchallenge/.

Sograve, Manasseh. 2019. "Statement by the Prime Minister Hon. Mannaseh Sogavare on Swith to China." Solomon Times, 20 September. Diakses pada 21 September 2019, https://www.solomontimes.com/news/statement-by-the-prime-minister-honmanasseh-soga vare-on-switch-to-china/9362.

Yin, Ozzy and Frances Huang. 2018. "More allies voice support for Taiwan's inclusion in UN activities." Focus Taiwan, 29 September. Diakses pada 20 Oktober 2019. http://focustaiwan.tw/news/aipl/201809290003.aspx.

Zamiska, N. dan Dean J. 2006. "Treasure islands: China and Taiwan spar over friends in small places." Wall Street Journal, 9 May. Diakses pada 19 Oktober 2019. http://www.news.vu/en/news/InternationalMediaCoverage/060509-ChinaandTaiwan- $\quad$ Spar-Over-Vanuatu.shtml.

Zhang, Denghua. 2019. "Perceiving China's Influence in the Pacific: The Case of Solomon Islands." The Diplomat, 18 Oktober. Diakses pada 21 Oktober 2019. $\mathrm{http}: / /$ thediplomat.com/2019/10/perceiving-chinas-influence-in-the-pacific-thecase- of-solomon- is lands/.

Zhang, Denghua and Transform Aqorau. 2019. "Diplomatic Switch? Solomon Islands relations with Taiwan or China." The Diplomat, 18 Maret. Diakses pada 21 Oktober 2019. $\quad$ https://www.lowyinstitute.org/the-interpreter/diplomaticswitch-solomon-islands- relations-taiwan-or-china. 